OPEN ACCESS

Edited by: John L. Provis,

University of Sheffield, United Kingdom

Reviewed by:

Chandan Pandey,

Indian Institute of Technology

Jodhpur, India

Antonio Caggiano,

Darmstadt University of Technology,

Germany

*Correspondence:

Xiao-Le Cheng

chengxiaole@xpu.edu.cn

Specialty section:

This article was submitted to

Structural Materials,

a section of the journal

Frontiers in Materials

Received: 31 July 2019

Accepted: 22 October 2019

Published: 26 November 2019

Citation:

Cheng X-L, Zhou S-J, Xu G-S, Fu H-G and Bai B-Z (2019) Study on Corrosion Resistance and Welding Properties of High Strength, Tough Bainite Steel CB10.

Front. Mater. 6:281.

doi: 10.3389/fmats.2019.00281

\section{Study on Corrosion Resistance and Welding Properties of High Strength, Tough Bainite Steel CB10}

\author{
Xiao-Le Cheng ${ }^{1,2 *}$, Si-Jun Zhou ${ }^{1}$, Guang-Shen $\mathrm{Xu}^{1}{ }^{1}$, Han-Guang Fu ${ }^{3}$ and Bing-Zhe Bai ${ }^{4}$ \\ ${ }^{1}$ School of Mechanical and Electrical Engineering, Xi'an Polytechnic University, Xi'an, China, ${ }^{2}$ State Key Laboratory of Metal \\ Extrusion and Forging Equipment Technology, Xi'an, China, ${ }^{3}$ College of Materials Science and Engineering, Beijing University \\ of Technology, Beijing, China, ${ }^{4}$ Department of Materials Science and Engineering, Tsinghua University, Beijing, China
}

In order to achieve high strength and toughness in bainite steel, the authors carried out a study on their self-developed CB10 steel. The CB10 steel was heat-treated at different tempering temperatures to control its microstructure and mechanical capabilities, and, further, changes in its structure were explored. The results showed that bainite, ferrite, and $\mathrm{M} / \mathrm{A}$ islands could be engendered when $\mathrm{CB} 10$ steel was tempered at $250^{\circ} \mathrm{C}, 450^{\circ} \mathrm{C}$, $600^{\circ} \mathrm{C}$, and $670^{\circ} \mathrm{C}$, respectively. With an increase in tempering temperature, lath-type bainite began to merge and coarsen obviously, and polygonal ferrite appeared. When the tempering temperature was above $600^{\circ} \mathrm{C}$, recovery and recrystallization occurred in some regions. In particular, the mechanical properties of $\mathrm{CB} 10$ steel were best at a $450^{\circ} \mathrm{C}$ tempering temperature; among them, its tensile strength was $632 \mathrm{MPa}$, its yield strength was $487 \mathrm{MPa}$, elongation was 25\%, and the Charpy absorbed energy was >140 J. Furthermore, the anti-hydrogen-induced cracking performance and weldability of CB10 steel were tested. The results indicated that there were no cracks on the surface of the sample, indicating that it has excellent anti-hydrogen-induced cracking performance and weldability. Moreover, the maximum hardness of the heat-affected zone was $231 \mathrm{Hv}$, the maximum Charpy absorbed energy was $285.0 \mathrm{~J}$, and the fracture morphology was in all cases ductile fracture when the impact temperature was above $-60^{\circ} \mathrm{C}$.

Keywords: bainite steel, hydrogen-induced cracking (HIC), welding, impact toughness, ductile fracture

\section{INTRODUCTION}

Currently, bainite steel is widely used in rail transit, bearing manufacturing, petroleum pipelines, construction machinery, automobiles, and other fields because of its high strength and toughness (Caballero et al., 2013; Singh and Singh, 2018; Tan et al., 2018; Zhao et al., 2018). In addition, the characteristics of hydrogen-induced cracking (HIC) resistance and good weldability, etc. are also needed for submarine pipeline steel. In general, as its yield strength rises, the plasticity and Charpy absorbed energy of bainite steel will be decreased. As the main elemental component in bainite steel, carbon is an interstitial solid-solution strengthening element that can improve the strength of the steel, but high carbon content will also increase brittleness and reduce weldability. Previous results show that the weldability of bainite steel can be improved by adding alloy elements such as Mo and B (Kang et al., 2018; Tereshchenko et al., 2018), but this will also increase cost. 
Furthermore, ultra-low carbon bainite steel, which was designed for ultra-low carbon and micro-alloying, could be strengthened by means of fine-grain strengthening, dislocation, and sub-structure strengthening while ensuring its toughness, so that the strength and toughness of ultra-low carbon bainite steel are matched well (Jiang et al., 2016; He et al., 2017; Zong and Liu, 2018). Recently, nano-bainite steel has attracted the interest of many researchers due to its excellent mechanical properties (Beladi et al., 2017; Singh et al., 2018; Zhao et al., 2018). The ultimate tensile strength, yield strength, hardness, and fracture toughness of nano-bainite steel can reach $2.5 \mathrm{GPa}$, $1.7 \mathrm{GP}, 600 \sim 700 \mathrm{HV}$, and $30-40 \mathrm{MPa} \cdot \mathrm{m}^{1 / 2}$, respectively, and its elongation can reach about 30\% after fracture (Fang et al., 2016). However, the weldability of the steel will be poor when the carbon content is about $0.8 \%$, and it is easy to produce cold cracks in welding, which seriously hinders its popularization and application (Fang et al., 2013). On the other hand, the bainite structure is a metastable structure (Long et al., 2018). In accordance with this characteristic, the bainite structure can be transformed by adopting proper tempering treatment (Wang et al., 2019), thereby improving its mechanical and welding performances. The purpose of this study was to heat-treat CB10 steel, which had been self-developed, at different tempering temperatures to control its microstructure, to explore changes in its structure so as to obtain high strength and toughness bainite steel, and to discuss its corrosion resistance and weldability.

\section{EXPERIMENTS}

\section{Preparation of Materials}

Self-developed bainite steel CB10 is used in the following investigations. The specific rolling process parameters are as follows: billet heating temperature $1,250^{\circ} \mathrm{C}$, held for $1 \mathrm{~h}$, initial rolling temperature $1,180^{\circ} \mathrm{C}$, finishing rolling temperature $1,050^{\circ} \mathrm{C}$, cumulative deformation $60 \%$, and final thickness of steel plate $30 \mathrm{~mm}$; final air cooling.

After rolling, samples were heated to the required temperatures $\left(250^{\circ} \mathrm{C}, 450^{\circ} \mathrm{C}, 600^{\circ} \mathrm{C}\right.$, and $\left.670^{\circ} \mathrm{C}\right)$, held for $1 \mathrm{~h}$, then air-cooled to room temperature (RT). The microstructural evolution and changes in mechanical properties at different tempering temperatures were then analyzed.

\section{HIC Test}

A HIC test of CB10 steel was carried out in strict accordance with $\mathrm{GB} / \mathrm{T}$ 8650-2015. In the $\mathrm{H}_{2} \mathrm{~S}$ corrosion test, the sample size is 28 $\times 20 \times 100 \mathrm{~mm}$, produced using wire cutting technology. The testing solution chosen was solution $\mathrm{A}$, which consists of $5.0 \mathrm{wt} \%$ $\mathrm{NaCl}$ and $0.50 \mathrm{wt} \% \mathrm{CH}_{3} \mathrm{COOH}$ in deionized water. The initial
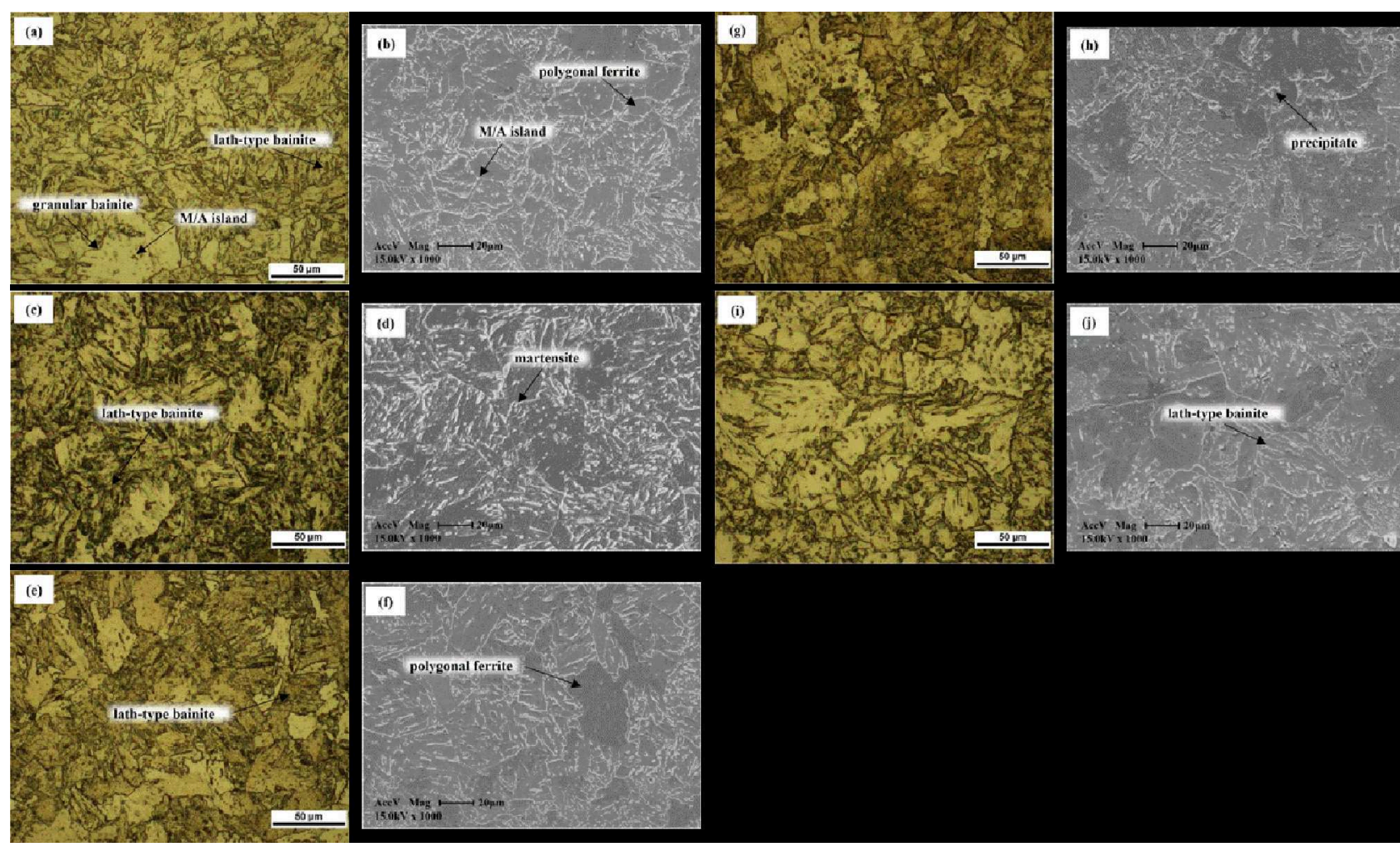

FIGURE 1 | Optical microstructures and SEM images of CB10 steel at various tempering temperatures: (a) optical microstructures as rolled, (b) SEM of CB10 steel as rolled, (c) optical microstructure of $\mathrm{CB} 10$ steel tempered at $250^{\circ} \mathrm{C}$, (d) SEM of $\mathrm{CB} 10$ steel tempered at $250^{\circ} \mathrm{C}$, (e) optical microstructure of $\mathrm{CB} 10$ steel tempered at $450^{\circ} \mathrm{C}$, (f) SEM of CB10 steel tempered at $450^{\circ} \mathrm{C}$, (g) optical microstructure of CB10 steel tempered at $600^{\circ} \mathrm{C}$, (h) SEM of $\mathrm{CB} 10$ steel tempered at $600^{\circ} \mathrm{C}$, (i) optical microstructure of $\mathrm{CB} 10$ steel tempered at $670^{\circ} \mathrm{C}$, (j) SEM of $\mathrm{CB} 10$ steel tempered at $670^{\circ} \mathrm{C}$. 
$\mathrm{pH}$ value was $2.8 \pm 0.1$. Finally, the macro surface cracks and micro-structure of the samples were observed, and the anti-HIC performance of CB10 steel was evaluated by three parameters: crack sensitivity rate (CSR), crack length rate (CLR), and crack thickness rate (CTR). The formulas are as follows:

$$
\begin{aligned}
C_{S R} & =\frac{\sum(a \times b)}{(W \times T)} \times 100 \% \\
C_{L R} & =\frac{\sum a}{W} \times 100 \% \\
C_{T R} & =\frac{\sum b}{T} \times 100 \%
\end{aligned}
$$

where a is crack length, b is crack thickness, $\mathrm{W}$ is sample width, and $\mathrm{T}$ is sample thickness. The unit is $\mathrm{mm}$.

\section{Welding Test}

A welding trial of CB10 steel was carried out in strict accordance with GBT 32260.2-2015 "Part 2: Self-restraint test, weldability testing method of Y-groove cracking test.” Specifically, manual arc welding was applied for the restraint weld, and J607 alkaline electrodes were used for the electrodes. Equally important, before being welded, the welding rods were dried for $2 \mathrm{~h}$ at $350^{\circ} \mathrm{C}$. The parameters used in the weld trails are welding voltage $\mathrm{U} 24 \mathrm{~V}$, welding current I 170A, and welding speed V $155 \mathrm{~mm} / \mathrm{min}$. Three temperatures, $\mathrm{RT}, 50^{\circ} \mathrm{C}$, and $70^{\circ} \mathrm{C}$, were used to preheat the specimens before welding the test welding line. Finally, surface cracks and microstructures in the weld zone were observed, the

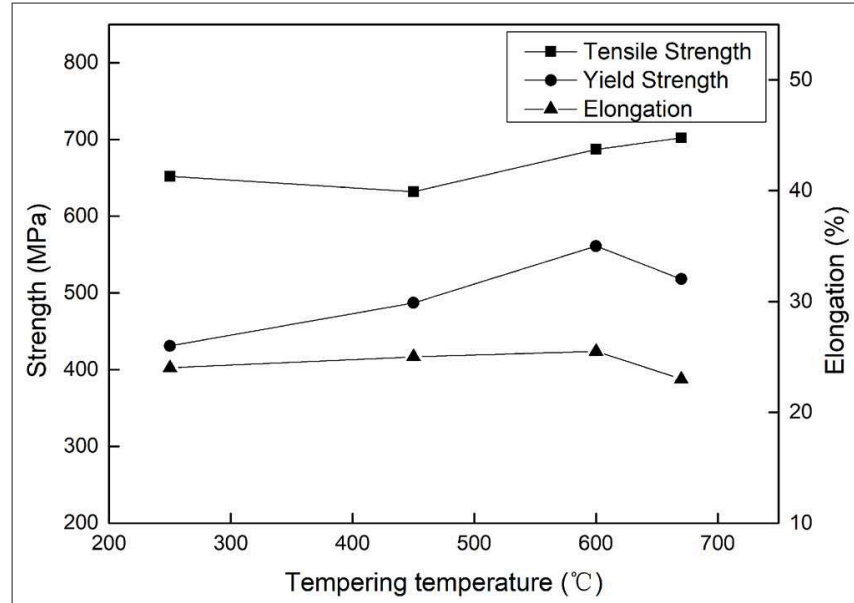

FIGURE 2 | Mechanical properties and elongation vs. tempering temperature for CB10 steel.

TABLE 1 | Charpy absorbed energy of CB10 steel at $-30^{\circ} \mathrm{C}$ vs. tempering temperature.

\begin{tabular}{lcccc}
\hline $\begin{array}{l}\text { Tempering } \\
\text { temperature } /{ }^{\circ} \mathbf{C}\end{array}$ & $\mathbf{2 5 0}$ & $\mathbf{4 5 0}$ & $\mathbf{6 0 0}$ & $\mathbf{6 7 0}$ \\
\hline $\begin{array}{l}\text { Charpy absorbed } \\
\text { energy }\left(30^{\circ} \mathrm{C}\right) / \mathrm{J}\end{array}$ & 23 & $>140$ & 43 & 10
\end{tabular}

Vickers hardness of the welded joint was measured, and the impact fracture morphology was judged by Charpy impact test.

\section{Microstructure Observation}

The microstructure was examined with a MEF4M microscope and image analysis system and a JSM-6301F scanning electron microscope (SEM). The metallographic samples were corroded by a $4 \%$ (volume fraction) nitric acid alcohol solution.

\section{RESULTS AND DISCUSSION Evolution of Microstructure During Tempering}

The microstructures of CB10 steel after tempering at different temperatures are shown in Figure 1. From Figures 1a,b, it can be seen that the rolling structures of CB10 steel are mainly composed of granular bainite, polygonal ferrite, retained austenite, and finer lath-type bainite in the original austenite

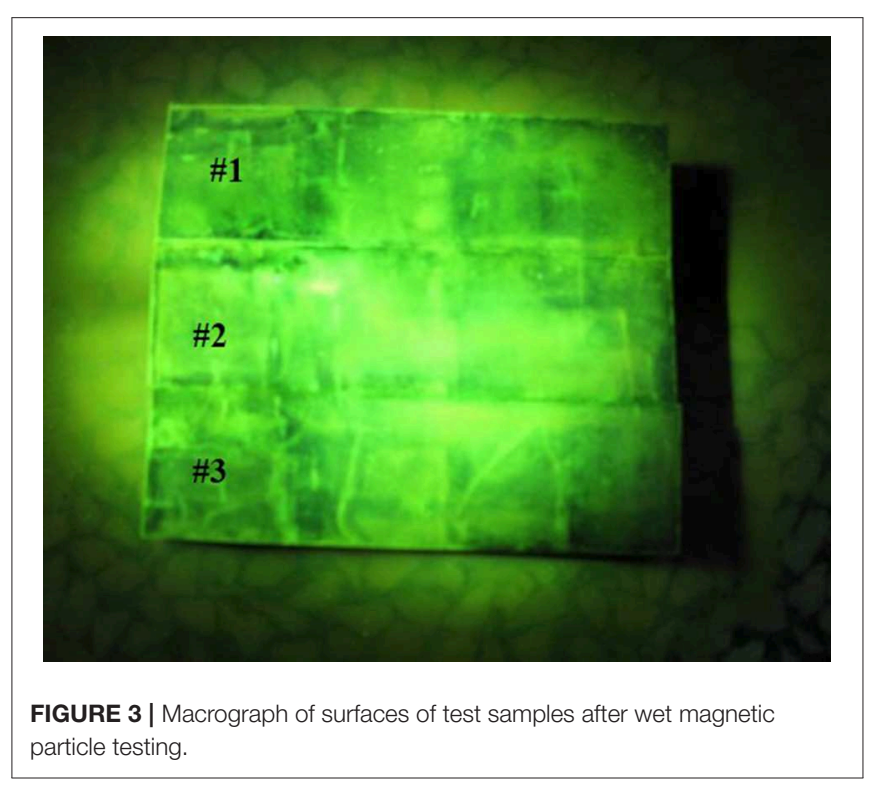

TABLE 2 | HIC performance tests of CB10 steel.

\begin{tabular}{lcccl}
\hline $\begin{array}{l}\text { Test } \\
\text { samples }\end{array}$ & $\begin{array}{c}\text { CSR } \\
\text { /\% }\end{array}$ & $\begin{array}{c}\text { CLR } \\
\text { /\% }\end{array}$ & $\begin{array}{c}\text { CTR } \\
\text { /\% }\end{array}$ & Hydrogen bubble \\
\hline$\# 1$ & 0 & 0 & 0 & No bubble \\
$\# 2$ & 0 & 0 & 0 & No bubble \\
$\# 3$ & 0 & 0 & 0 & No bubble \\
\hline
\end{tabular}

TABLE 3 | Grade of non-metallic inclusions in CB10 steel.

\begin{tabular}{lcccc}
\hline Grade & $\begin{array}{c}\text { Sulfide } \\
\text { A }\end{array}$ & $\begin{array}{c}\text { Oxide } \\
\text { B }\end{array}$ & $\begin{array}{c}\text { Silicate } \\
\text { C }\end{array}$ & $\begin{array}{c}\text { Spheroidal oxide } \\
\text { D }\end{array}$ \\
\hline$\# 1$ & 0.5 & 0.5 & $0.5 e$ & $1.510 .5 \mathrm{e}$ \\
$\# 2$ & 0.5 & 0.5 & 0 & $1.510 .5 \mathrm{e}$ \\
\hline e, coarse-grained inclusion. & & &
\end{tabular}



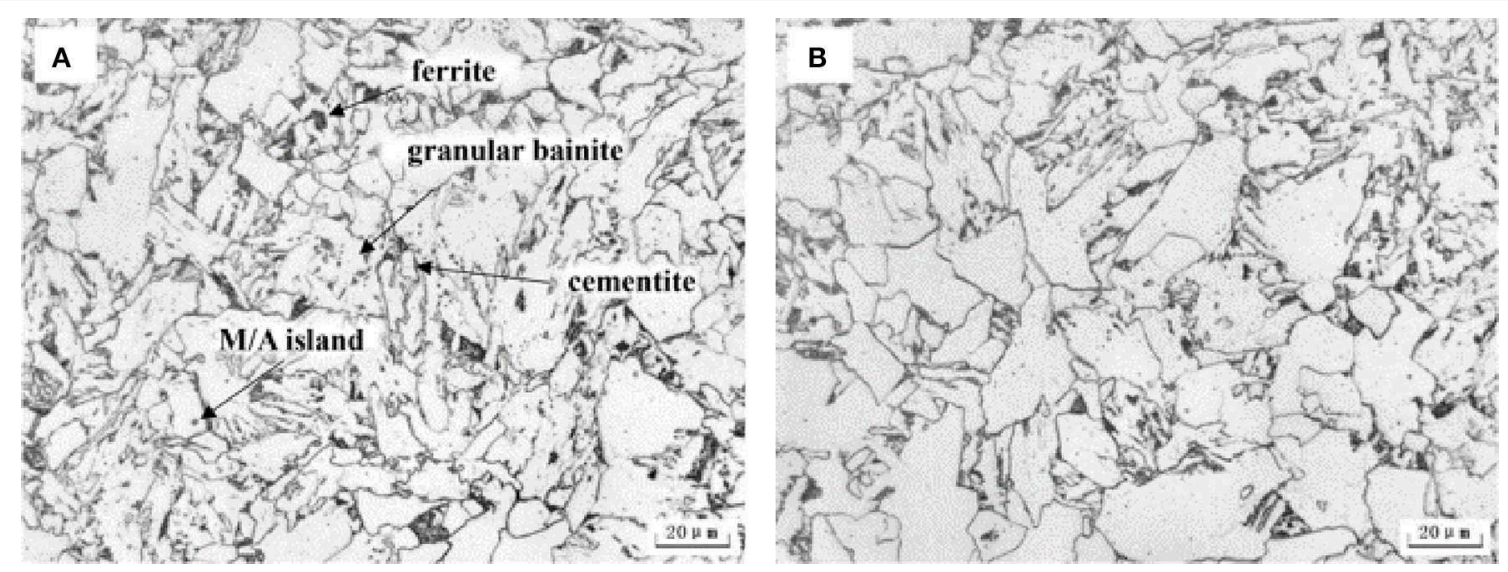

FIGURE 4 | Microstructure of CB10 steel after HIC. (A) Test sample \#1, (B) test sample \#2.
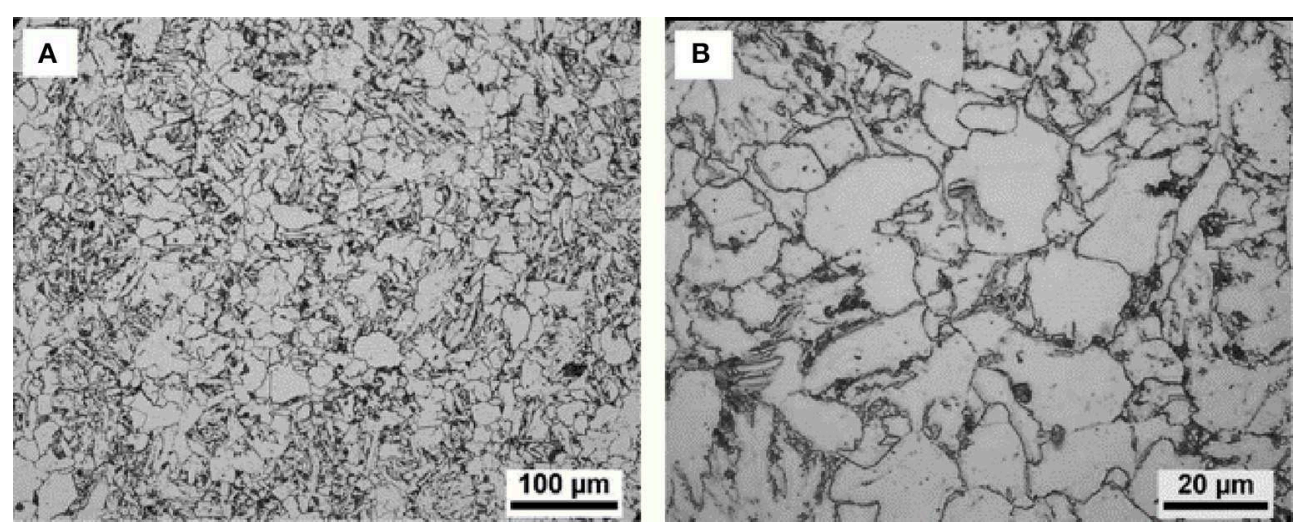

FIGURE 5 | Microstructure of CB10 steel, showing the grain size after HIC. (A) Test sample \#1, (B) test sample \#2.

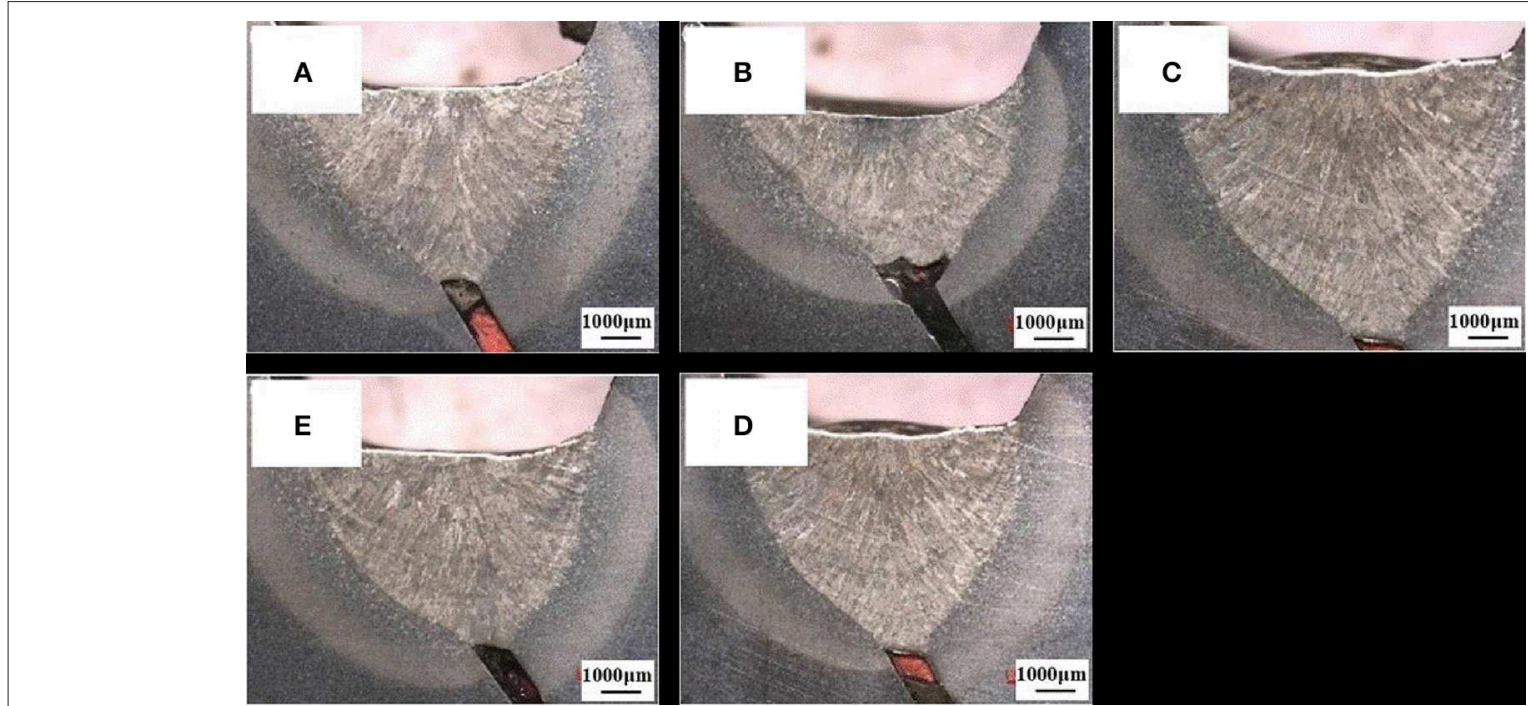

FIGURE 6 | Macrograph of the weld line cross-section of a test sample preheated to $50^{\circ} \mathrm{C}$. (A-E) Show from the initial end to the crater. 
grains. Obviously, the granular bainite is composed of ferrite and M/A islands, which are bright yellow, and the lathtype bainite, which is dark yellow (Figure 1a). When the tempering temperature is $250^{\circ} \mathrm{C}$ (Figures $\mathbf{1 c}, \mathbf{d}$ ), the interfaces of lath-type bainites begin to become blurred. The retained austenite is decomposed into martensite surrounded by some larger polygonal ferrite, i.e., a martensite ring, which is bright white (Figure 1d). While the tempering temperature is increased to $450^{\circ} \mathrm{C}$ (Figures 1e,f), some lath-type bainites began to coarsen, M/A islands are gradually decomposed, and larger polygonal ferrites appear. When the tempering temperature reaches $600^{\circ} \mathrm{C}-670^{\circ} \mathrm{C}$ (Figures $1 \mathbf{g}-\mathbf{j}$ ), recovery and recrystallization occur in some areas. There are definitely precipitates in Figure 1g. The boundaries of lath-type bainites are blurred. When the tempering temperature reaches $670^{\circ} \mathrm{C}$, lath-type bainites merge, and the structure is obviously coarsened (Figure 1j).

\section{Mechanical Properties After Tempering}

The tensile performance and impact toughness of CB10 steel were tested and calculated after tempering at different temperatures, and the corresponding curves were drawn (Figure 2). Figure 2 shows that with an increase in tempering temperature, tensile strength increased slightly from 652 to $702 \mathrm{MPa}$, and yield strength increased from 431 to $561 \mathrm{MPa}$ and then fell a little. Specifically, when the tempering temperature is between $250^{\circ} \mathrm{C}$ and $600^{\circ} \mathrm{C}$, yield strength trends upward obviously, which is due to precipitation of cementite. The elongation is insensitive to tempering temperature, with an average value of $24.3 \%$ and fluctuations of $<1.3 \%$. Table 1 shows that with an increase in tempering temperature, the Charpy absorbed energy is initially enhanced, followed by a decline; it reaches a peak value of $>140 \mathrm{~J}$ at a tempering temperature of $450^{\circ} \mathrm{C}$, which is beyond the range of the instrument. Because the brittle phase, $\mathrm{M} / \mathrm{A}$ islands, is gradually lost, lath-type bainite is coarsened and forms a soft-tough tissue.

In conclusion, CB10 steel exhibits excellent mechanical properties after tempering at $450^{\circ} \mathrm{C}$. Therefore, CB10 steel under this condition was selected for HIC testing and welding performance testing.

\section{Anti-HIC Performance}

The samples were tested and analyzed by wet magnetic particle testing in a RT environment (at a humidity of

TABLE 4 | Microhardness of the $\mathrm{HAZ}$ at a preheating temperature of $50^{\circ} \mathrm{C}$.

\begin{tabular}{lccccc}
\hline Sample & $\begin{array}{c}\text { Base } \\
\text { metal }\end{array}$ & $\begin{array}{c}\text { Intercritical } \\
\text { zone }\end{array}$ & $\begin{array}{c}\text { Fine-grained } \\
\text { heat-affected } \\
\text { zone }\end{array}$ & $\begin{array}{c}\text { Coarse-grained } \\
\text { heat-affected } \\
\text { zone }\end{array}$ & $\begin{array}{c}\text { Fusion } \\
\text { zone }\end{array}$ \\
\hline $1 / \mathrm{Hv}$ & 178 & 205 & 203 & 228 & 248 \\
$2 / \mathrm{Hv}$ & 184 & 208 & 196 & 212 & 236 \\
$3 / \mathrm{Hv}$ & 178 & 203 & 194 & 242 & 239 \\
$4 / \mathrm{Hv}$ & 180 & 209 & 192 & 244 & 245 \\
$5 / \mathrm{Hv}$ & 181 & 205 & 196 & 231 & 242 \\
Average/Hv & 180 & 206 & 196 & 231 & 242
\end{tabular}

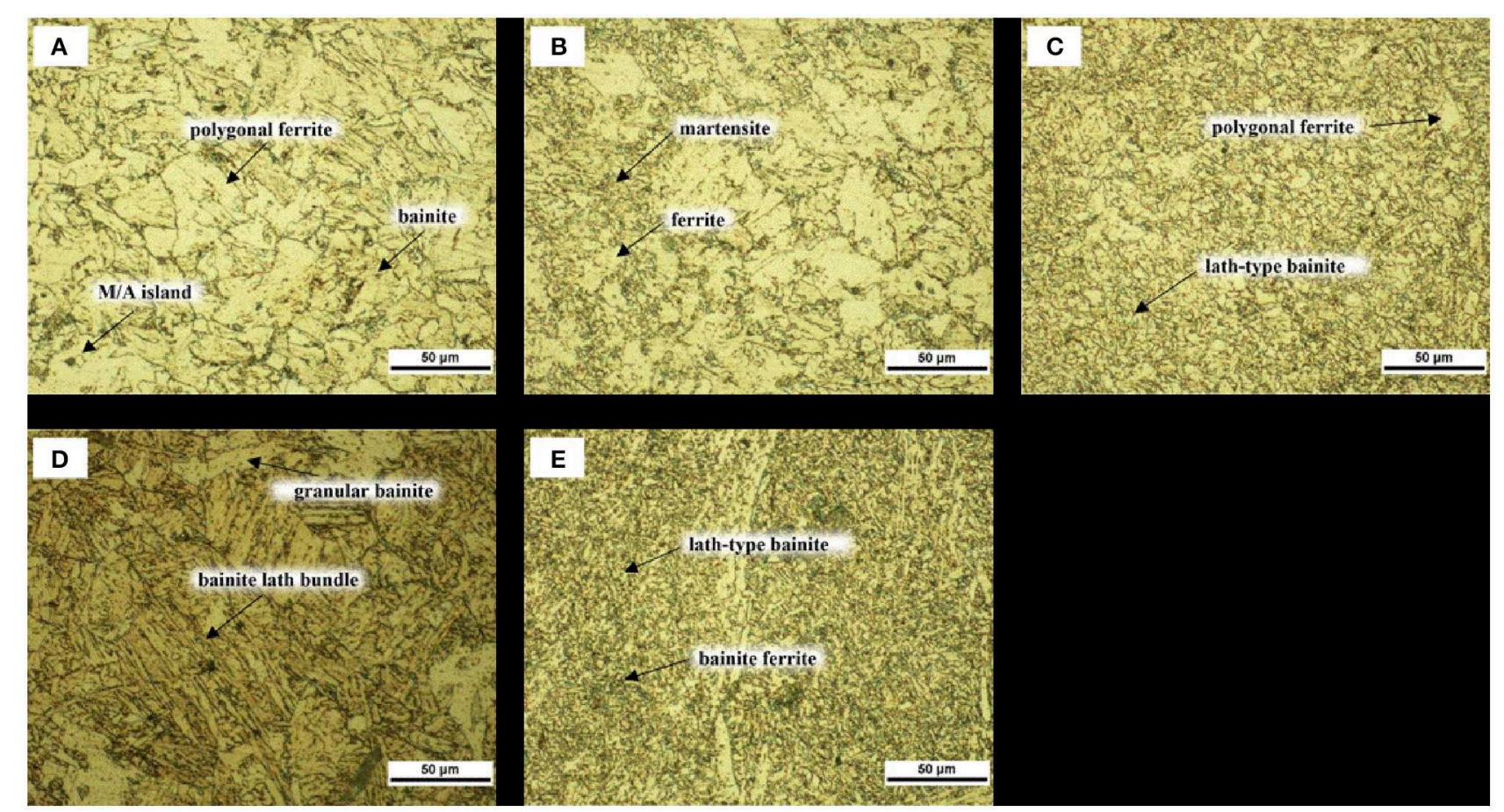

FIGURE 7 | Optical microstructure in the HAZ zone of CB10 steel with preheating to $50{ }^{\circ} \mathrm{C}$ : (A) Base metal, (B) Intercritical zone, (C) Fine-grained heat-affected zone, (D) Coarse-grained heat-affected zone, (E) Fusion zone. 
40\%) (Figure 3 and Table 2, separately). The results show that there was no hydrogen bulging and cracking on the surface of the samples; the surface was totally intact. This was owing to there being little content of non-metallic inclusions in CB10 steel (Table 3), with only a small amount of sulfide, oxide, silicate, and spheroidal oxide non-metallic inclusions, which effectively controls the enhancement of HIC sensitivity and causes the steel to have excellent antiHIC performance.

The microstructures of the samples were examined after HIC (Figure 4). From Figure 4A, it is clear that ferrite, granular bainite, and a small amount of cementite are the main components of sample \#1. Among them, the ferrite is mainly distributed near grain boundaries, and M/A islands are finely dispersed, which prevents grain rise and decreases the yield ratio. Figure 4B shows that, compared with sample \#1, the granular bainite is larger and the ferrite content ratio is lower in sample \#2. Additionally,

TABLE 5 | Results of Charpy V-notch of the HAZ/J.

\begin{tabular}{|c|c|c|c|c|c|c|c|}
\hline \multirow{3}{*}{$\begin{array}{l}\text { Impact } \\
\text { temperature } \\
/^{\circ} \mathrm{C}\end{array}$} & \multicolumn{7}{|c|}{ AKv of different preheating temperatures $/{ }^{\circ} \mathrm{C}$} \\
\hline & \multirow{2}{*}{$\frac{\mathrm{RT}}{1}$} & \multicolumn{3}{|c|}{50} & \multicolumn{3}{|c|}{70} \\
\hline & & 1 & 2 & Average & 1 & 2 & Average \\
\hline-20 & 286.0 & 284.9 & 298.0 & 291.5 & 278.0 & 277.0 & 277.5 \\
\hline 0 & 299.9 & 285.0 & 290.0 & 287.5 & 299.9 & 270.0 & 285.0 \\
\hline 20 & 290.0 & 283.0 & 282.0 & 282.5 & 229.0 & 254.0 & 241.5 \\
\hline
\end{tabular}

the grain size grade of CB10 steel was tested (Figure 5). The grain size grades of samples \#1 and \#2 are both 7.0, so they are considered fine-grained. In other words, proper grain refinement of $\mathrm{CB} 10$ steel can also improve its antiHIC performance.

\section{Weldability}

\section{Y-Groove Cracking Weldability Testing}

Y-groove cracking tests were carried out at diverse preheating temperatures of RT, $50^{\circ} \mathrm{C}$, and $70^{\circ} \mathrm{C}$. Surface cracks and crosssection cracks were also analyzed. It is apparent that there was no cracking on the surfaces and cross-sections of the samples; both the surface crack rate and cross-section crack rate are zero. These results indicate that $\mathrm{CB} 10$ steel has low cold crack sensitivity and good weldability. In particular, when the thickness of the plate is $30 \mathrm{~mm}$ and there is no pre-heating before welding, there is no cold cracking during welding. Figure 6 presents crosssectional macroscopic images of a weld seam from the initial end to the crater at a preheating temperature of $50^{\circ} \mathrm{C}$, showing excellent weldability.

The microstructures and hardness of the welded joint in Figure 6C were observed and tested (Figure 7 and Table 4, respectively). The base metal zone of the sample (Figure 7A)

TABLE 6 | Results of Charpy V-notch FATT tests.

\begin{tabular}{lccccc}
\hline Impact temperature $/{ }^{\circ} \mathbf{C}$ & $\mathbf{- 6 0}$ & $\mathbf{- 4 0}$ & $\mathbf{- 2 0}$ & $\mathbf{0}$ & $\mathbf{2 0}$ \\
\hline $\mathrm{AKV} / \mathrm{J}$ & 257 & 298 & 296.3 & $>300$ & 271
\end{tabular}
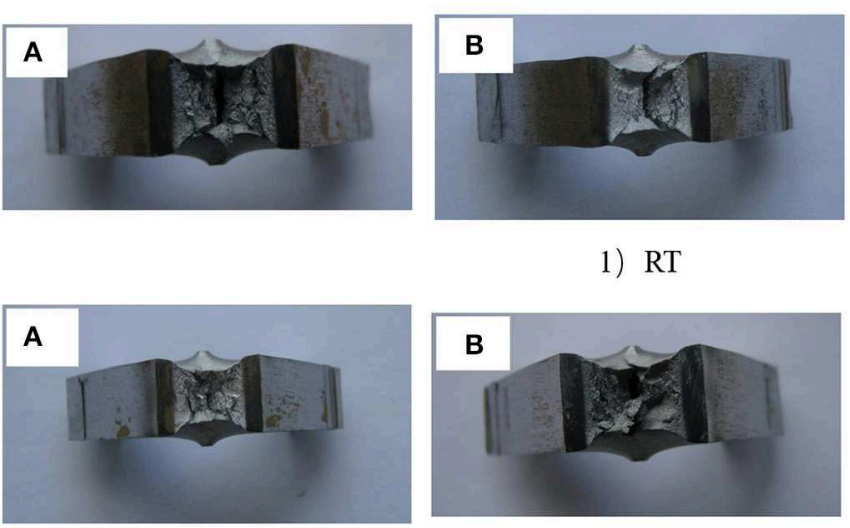

2) $50^{\circ} \mathrm{C}$

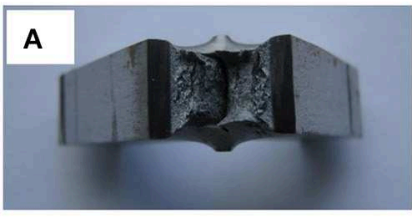

1) $\mathrm{RT}$
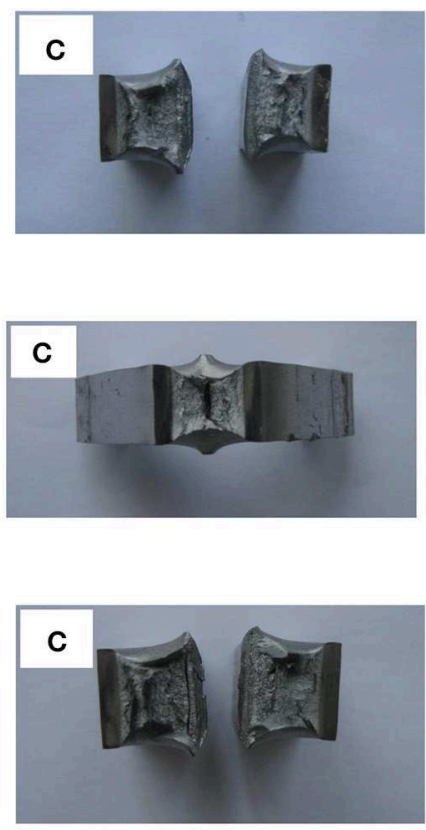

3) $70^{\circ} \mathrm{C}$

FIGURE 8 | Fracture morphology at various impact temperatures and preheating temperatures. (1) RT: (A) $-20^{\circ} \mathrm{C}$, (B) $0^{\circ} \mathrm{C}$, (C) $20^{\circ} \mathrm{C}$. (2) $50^{\circ} \mathrm{C}$ : (A) $-20^{\circ} \mathrm{C}$, (B) $0^{\circ} \mathrm{C}$, (C) $20^{\circ} \mathrm{C}$. (3) $70^{\circ} \mathrm{C}:$ (A) $-20^{\circ} \mathrm{C}$, (B) $0^{\circ} \mathrm{C}$, (C) $20^{\circ} \mathrm{C}$. 
is mainly composed of polygonal ferrite, bainite, and a small number of $\mathrm{M} / \mathrm{A}$ islands. The intercritical zone (Figure 7B) contains ferrite of diverse sizes and fine martensite phases and can hence be characterized as having uneven microstructures. Austenite in the fine-grained heat-affected zone (Figure 7C) underwent phase transformation recrystallization under high temperature, resulting in fine and uniform lath-type bainite and a small amount of polygonal ferrite. Bainite lath bundles consisting of lath-type bainite appear in the coarse-grained heataffected zone (Figure 7D) as a result of an overly high heating temperature, which divides austenite grains and M/A islands and produces granular bainite. Bainite ferrite, fine lath-type bainite, and retained austenite are the main components in the fusion zone (Figure 7E).

The hardness measurements of the welded joints are shown in Table 4. The results indicate that the maximum microhardness of the HAZ is $231 \mathrm{Hv}$ in the coarse-grained heat-affected zone. This results from the formation of M/A islands, brittle phases of granular bainite, and, more seriously, the coarsening of the tissue. Therefore, the coarse-grained heat-affected zone and fusion zone became weaker links in welded joints.

\section{Charpy V-Shaped Notch in HAZ}

Table 5 lists the measured results for the Charpy absorbed energy of the samples at various impact temperatures. The results indicate that the Charpy absorbed energy is lessened with an increase in impact temperature. The higher the impact temperature, the greater the Charpy absorbed energy.

In the meantime, with an increase in impact temperature, the degree of plastic deformation at the edge of the impact fracture increases, and the fracture morphology is in all cases ductile fracture.

The impact fracture morphologies of welded joints of $\mathrm{C} 10$ steel at impact temperatures of $-20^{\circ} \mathrm{C}, 0^{\circ} \mathrm{C}$, and $20^{\circ} \mathrm{C}$ are presented in Figures $8(\mathbf{A} \mathbf{A}, \mathbf{B}),(2 \mathrm{~A}, \mathbf{B}),(3 \mathrm{~A}, \mathbf{B})$. In short, the macro-morphologies of the welded joints are basically similar. The fractures are almost entirely made up of fiber areas and shear lips, which shows that CB10 steel has excellent toughness and high Charpy absorbed energy. In particular, when the impact temperature is $20^{\circ} \mathrm{C}$ [Figures $\mathbf{8}(\mathbf{1 C}, \mathbf{2 C}, \mathbf{3 C})$ ], there are radiation areas and stratification phenomena in the fracture area. Although the brittleness has climbed and the impact absorption power has been reduced, the material still maintains good toughness. With respect to the delamination phenomenon, inhomogeneous structure or micro-defects are seen in the middle part of the microstructure of CB10 steel.

\section{Ductile-Brittle Transition Temperature of CB10}

Table 6 presents the measured results of Charpy absorbed energy at various impact temperatures. It illustrates that the Charpy absorbed energy of CB10 steel can reach more than $300 \mathrm{~J}$ at impact temperatures ranging from $-60^{\circ} \mathrm{C}$ to $20^{\circ} \mathrm{C}$. By comparing the data in Table 6 with the ductile-brittle transition temperature curve, it can be found that the impact fracture morphology is ductile fracture when the impact temperature ranges from $-60^{\circ} \mathrm{C}$ to $20^{\circ} \mathrm{C}$; in brief, these are all above the brittle transition temperature region (Gao et al., 2011, 2015; Figure 9).

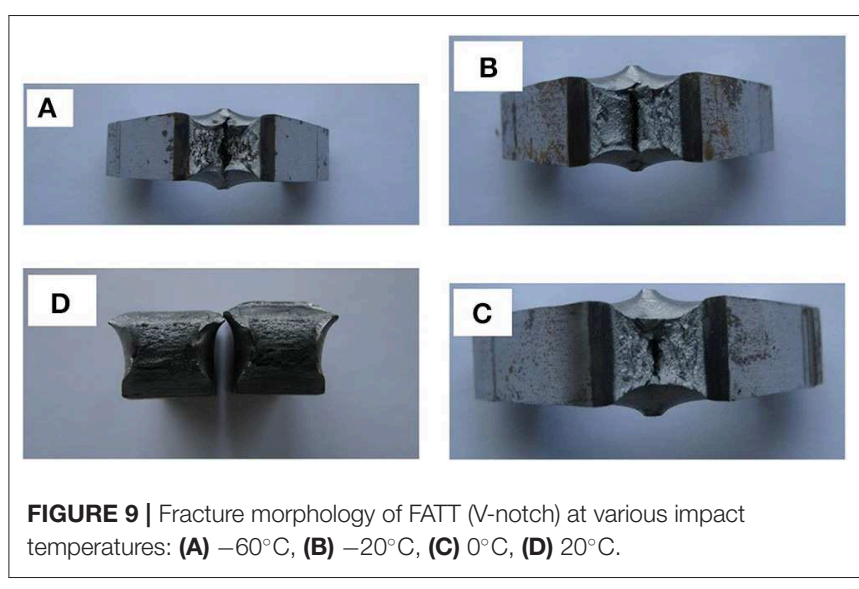

\section{CONCLUSION}

(1) A bainite, ferrite, and M/A island structure could be obtained when $\mathrm{CB} 10$ steel was tempered at $250^{\circ} \mathrm{C}, 450^{\circ} \mathrm{C}, 600^{\circ} \mathrm{C}$, and $670^{\circ} \mathrm{C}$.

(2) With an increath-type bainite began to merge and coarsen obviously, a nd polygonal ferrite appeared. When the tempering temperature was above $600^{\circ} \mathrm{C}$, recovery and recrystallization occurred in some regions.

(3) The mechanical properties of CB10 steel were best when the tempering temperature was $450^{\circ} \mathrm{C}$. The tensile strength was $632 \mathrm{MPa}$, the yield strength was $487 \mathrm{MPa}$, elongation was $25 \%$, and the Charpy absorbed energy was $>140 \mathrm{~J}$.

(4) The anti-HIC performance and weldability of tempered $\mathrm{CB} 10$ steel at $450^{\circ} \mathrm{C}$ was tested. The results showed that there were no cracks on the surface of the samples, showing that they had excellent anti-HIC performance and weldability. Only a few non-metallic inclusions existed in the steel, and the grain size was refined, which effectively improved its anti-HIC performance.

(5) The maximum hardness of HAZ was $231 \mathrm{Hv}$, which was due to the formation of M/A islands, brittle phases of granular bainite, and, more seriously, coarsening of the tissue. CB10 steel had excellent toughness and high Charpy absorbed energy. The higher the impact temperature, the greater the Charpy absorbed energy. The maximum Charpy absorbed energy was $284.95 \mathrm{~J}$.

(6) When the impact temperature was above $-60^{\circ} \mathrm{C}$, the fracture morphology was in all cases ductile fracture.

In recent years, research on bainite steel has moved from the development of new bainite steel varieties to the exploration of the bainite structure. From the point of view of meeting the market demand, it is very important to improve the properties of bainite steel by controlling its structure and morphology.

\section{DATA AVAILABILITY STATEMENT}

All datasets generated for this study are included in the article/supplementary material. 


\section{AUTHOR CONTRIBUTIONS}

This paper was mainly proposed and designed by X-LC and was discussed with S-JZ, G-SX, H-GF, and B-ZB. Among them, X-LC examined the evolution of the microstructure during tempering,

\section{REFERENCES}

Beladi, H., Tari, V., Timokhina, I. B., Cizek, P., Rohrer, G. S., Rollett, A. D., et al. (2017). On the crystallographic characteristics of nanoBainite steel. Acta Mater. 127, 426-437. doi: 10.1016/j.actamat.2017.01.058

Caballero, F. G., Allain, S., Cornide, J., Puerta Velásquez, J. D., Garcia-Mateo, C., and Miller, M. K. (2013). Design of cold rolled and continuous annealed carbide-free bainite steels for automotive application. Mater. Des. 49, 667-680. doi: 10.1016/j.matdes.2013.02.046

Fang, K., Song, K. J., Liang, N., et al. (2016). Effect of segregation on microstructure and propertiesof renano-bainitic steel weld. Trans. China Weld. Inst. 37, 71-74.

Fang, K., Song, K. J., Yang, J. G., et al. (2013). Microstructure and properties of TIG welded joint of nano bainitic steel. Trans. China Weld. Inst. 34, 13-16.

Gao, G. H., Gui, X. L., An, B. F., Tan, Z., Bingzhe, B., and Yuqing, W. (2015). Effect of finish cooling temperature on microstructure and low temperature toughness of $\mathrm{Mn}$ - series ultra-low carbon high strength low alloyed steel. Acta Metal. Sinica 51, 21-30. doi: 10.11900/0412.1961.2014.00329

Gao, G. H., Zhang, H., and Bai, B. Z. (2011). Effect of tempering temperature on low temperature impact toughness of a low carbon Mn-series bainitic steel. Acta Metal. Sinica 47, 513-519. doi: 10.3724/SP.J.1037.2010.00550

He, B. B., Xu, W., and Huang, M. X. (2017). Effect of boron on bainitic transformation kinetics after ausforming in low carbon steels. J. Mater. Sci. Technol. 33, 1494-1503. doi: 10.1016/j.jmst.2017.05.006

Jiang, Q. M., Zhang, X. Q., and Chen, L. Q. (2016). Weldability of $1000 \mathrm{MPa}$ grade ultra-low carbon bainite steel. J. Iron Steel Res. Int. 23, 705-710. doi: 10.1016/S1006-706X(16)30109-1

Kang, P., Yang, C., Fan, C., and Lin, S. (2018). Microstructure and mechanical properties of simulated unaltered coarse grained heat affected zones of $10 \mathrm{crni} 3 \mathrm{mov}$ steel by double-sided double arc welding. J. Mater. Process. Technol. 251, 225-231. doi: 10.1016/j.jmatprotec.2017. 08.032

Long, X., Zhang, F., Yang, Z., and Lv, B. (2018). Study on microstructures and properties of carbide-free and carbide-bearing bainite steels. Mater. Sci. Eng. A 715, 10-16. doi: 10.1016/j.msea.2017.12.108
B-ZB and S-JZ analyzed the mechanical properties after tempering and anti-HIC performance. G-SX and H-GF analyzed the welding properties of the samples. X-LC processed the results and wrote the paper. G-SX, H-GF, and B-ZB also revised the paper.

Singh, K., Kumar, A., and Singh, A. (2018). Effect of prior austenite grain size on the morphology of nano-bainite steels. Metal. Mater. Trans. A 49, 1348-1354. doi: 10.1007/s11661-018-4492-8

Singh, K., and Singh, A. (2018). Tribological response and microstructural evolution of nanostructured bainitic steel under repeated frictional sliding Wear 410-411, 63-71. doi: 10.1016/j.wear.2018.06.005

Tan, Z. L., Gao, B., Gao, G. H., Zhang, M., Gui, X., and Bai, B. (2018). Current development situation of bainitic rails at home and abroad. Heat Treat. Metals 43, 10-18. doi: 10.13251/j.issn.0254-6051.2018.04.002

Tereshchenko, N. A., Yakovleva, I. L., Mirzaev, D. A., and Buldashev, I. V. (2018). Features of isothermal formation of carbide-free bainite in high-carbon manganese-silicon steel. Phys. Metals Metal. 119, 569-575. doi: 10.1134/S0031918X18060145

Wang, B. H., Bai, B. Z., Ma, H. F., et al. (2019). Effect of temperature on yieldstrength ratio of $\mathrm{Nb}$-Ti microalloyed Mn-bainite steel. Chin. J. Rare Metals 43, 151-156. doi: 10.13373/j.cnki.cjrm.XY18090027

Zhao, J., Guo, K., He, Y. M., Wang, Y. F., and Wang, T. S. (2018). Extremely high strength achievement in medium-C nanobainite steel. Scr. Mater. 152, 20-23. doi: 10.1016/j.scriptamat.2018.04.005

Zong, Y., and Liu, C. M. (2018). Microstructure and properties of HAZ in lowcarbon bainite E550 steel during double-pass welding thermal cycle. Mater. Sci. Forum 913, 317-323. doi: 10.4028/www.scientific.net/MSF.913.317

Conflict of Interest: The authors declare that the research was conducted in the absence of any commercial or financial relationships that could be construed as a potential conflict of interest.

Copyright (c) 2019 Cheng, Zhou, Xu, Fu and Bai. This is an open-access article distributed under the terms of the Creative Commons Attribution License (CC BY). The use, distribution or reproduction in other forums is permitted, provided the original author(s) and the copyright owner(s) are credited and that the original publication in this journal is cited, in accordance with accepted academic practice. No use, distribution or reproduction is permitted which does not comply with these terms. 